\title{
Comparative and competitive advantages of nutmeg farming in two regions in Maluku Province, Indonesia
}

\author{
TIENNI MARIANA SIMANJORANG, IRHAM, LESTARI RAHAYU WALUYATI, \\ JANGKUNG HANDOYO MULYO \\ Department of Agricultural Socioeconomics, Faculty of Agriculture, Universitas Gadjah Mada. Jl. Flora, Bulaksumur, Sleman 55281, Yogyakarta, \\ Indonesia. Tel./fax.: +62-274-563062, `email: irham@ugm.ac.id
}

Manuscript received: 3 January 2019. Revision accepted: 22 February 2020.

\begin{abstract}
Simanjorang TM, Irham, Waluyati LR, Mulyo JH. 2020. Comparative and competitive advantages of nutmeg farming in two regions in Maluku Province, Indonesia. Biodiversitas 21: 1165-1173. Comparative and competitive advantage is one of the main keys to the development of nutmeg farming in Maluku Province to deal with globalization and market liberalization. Consequently, assessments are needed in developing efforts to improve the comparative and competitive advantage of nutmeg farming. The purposes of this study are to find out the private and social benefits of nutmeg farming, to find out the comparative and competitive advantages of nutmeg farming, and to compare the level of competitiveness of small-scale nutmeg farming in two regions in Maluku Province, Indonesia, namely the Ambon Island region and the Banda Islands region. Data were collected using direct interview techniques to smallholder nutmeg farmers selected purposively. The data was then analyzed using the Policy Analysis Matrix (PAM) and the tindependent test of difference. The results show that nutmeg farming in the Banda Islands region has higher private and social benefits than in the Ambon Island region, because the nutmeg farming system in Banda Islands region is carried out intensively and the price of nutmeg farms received by farmers is higher, The competitive and comparative advantage of nutmeg farming in the Banda Islands region is higher than in the Ambon Island region. All these results suggest that in general nutmeg farming in the Banda Islands region is more competitive than in the Ambon Island region.
\end{abstract}

Keywords: Competitiveness, competitive advantage, comparative advantage, nutmeg farming, Maluku

\section{INTRODUCTION}

Globalization and market liberalization create very tight competition for commodities sold in international markets. A substantial loss will be caused by globalization and market liberalization if a country does not have product competitiveness. Indonesia, as an agriculture-based country, has several superior commodities that can compete in the international market, one of which is nutmeg spices (Jambor et al. 2018). Nutmeg (Myristica fragrants Houtt.) is a spice plant species native to Indonesia and probably originated from the southern Moluccan Islands (Hasibuan et al. 2012). This species has been domesticated and used for centuries, and with current globalization, it has the potential to be developed as the main spice export commodity in the world (Gerungan et al. 2010; Jambor et al. 2018). Also, nutmeg and its derivatives (e.g. nutmeg and mace) provide benefits to fulfill human needs as well as being a mainstay commodity to support the economic growth and income at regional level (Hasibuan et al. 2012).

Free trade conditions and market liberalization need to be benefited in the context of countries that have a higher comparative and competitive advantage will have more exceptional ability to continue to exist in international markets (Stephenson dan Erwidodo, 1995). On a smaller scale of economy, competitiveness is closely related to the feasibility of a business to be developed economically (Rahman et al, 2016). For this reason, it is necessary to study the competitiveness of nutmeg farming in Indonesia.
The competitiveness of nutmeg farming must be viewed holistically, meaning that it is seen from its comparative and competitive advantages. Comparative advantage can be seen from the local resources owned, namely the abundance and condition of the land and the subject commodity (in this case nutmeg), labor, capital, and management capabilities (Zhong et al. 2001; Mohammadi, 2004; Shahnvshy et al. 2007; Zare, 2008). Competitive advantage is closely related to indicators representing the feasibility of activity or financial/private profit of a business, which is valued at the current price, both for the price of output, input, and exchange rate (Zheng et al, 2013; Alves et al, 2017). The main factor in competitive advantage is directly influenced by market distortion (government policies, both directly and indirectly) (Nayantakaningtyas dan Daryanto, 2012; Sousa et al. 2011).

Maluku Province was the fourth largest nutmeg producing province in Indonesia with the contribution of national nutmeg production of $14.65 \%$ after Aceh, North Maluku, and North Sulawesi Provinces (BPS of Maluku Province, 2018). Maluku Province itself is known as the province of a thousand islands, meaning that this province consists of 1027 large and small islands (BPS of Maluku Province, 2018). Nutmeg plants do not grow evenly on every island in the Maluku province. The islands that are the centers of nutmeg are the Banda Islands region and Ambon Island region, so these two regions contribute significantly to nutmeg production in Maluku Province. Nutmeg farming managed by farmers is still traditional, 
cultivated using polyculture system or often termed as agroforestry. Polyculture cultivation or agroforestry is often found in community forest lands (Salam dan Tufail, 2014; Adesina and Coulibaly, 1998) and not intensively managed so that the productivity of nutmeg farming tends to be stagnant or even decline (BPS of Maluku Province, 2018). The productivity of nutmeg farming in Maluku Province decreased in 2016 by 0.20 tons/ha, down to 0.19 tons/ha in 2017 (BPS of Maluku Province, 2018). This nutmeg commodity is a mainstay commodity of the region as a source of economic growth and income, as well as being the main commodity in the revitalization program of the Maluku Province plantations because it is a native plant of the region (BPS of Maluku Province, 2018). This research aims to determine the comparative and competitive advantages of nutmeg farming in different regions in Maluku Province, Indonesia. We expect the result can serve as baseline information for government at various levels which can determine the success of a product/ business that remains a leading sector in the region.

\section{MATERIALS AND METHODS}

\section{Study area}

The selection of research locations was carried out by purposive sampling and focused on the Banda Islands Region and Ambon Island Region since these area were the largest nutmeg-producing areas in Maluku province with $2,134.1$ tons $(42.35 \%)$ in which the Banda Islands region contributed 922.5 tons (39.52\%) and the Ambon Island region contributed 566.7 tons (19.99\%) (BPS of Maluku Province, 2018). For more details about the study area can be seen in Figure 1.

\section{Data collection}

The primary data collection was conducted from March to May 2019, using direct interview techniques to smallholder nutmeg farmers using a questionnaire. Primary data collected included the characteristics of nutmeg farmers, nutmeg farming management, marketing, and others. The method in determining respondents used purposive sampling, by selecting smallholder nutmeg farmers who owned productive nutmeg plants of more than 6 years old.

The method of taking the number of respondents was done by quota technique in which for each region (i.e. Banda Islands and Ambon Island) we determined 60 people, totaling 120 respondents. Quota technique is a method of determining the number of respondents by setting a certain number of respondents so that it reflects the population (Dattalo 2008). Quota technique was used in this study because the data on the population of nutmeg farmers in the two regions was unknown.
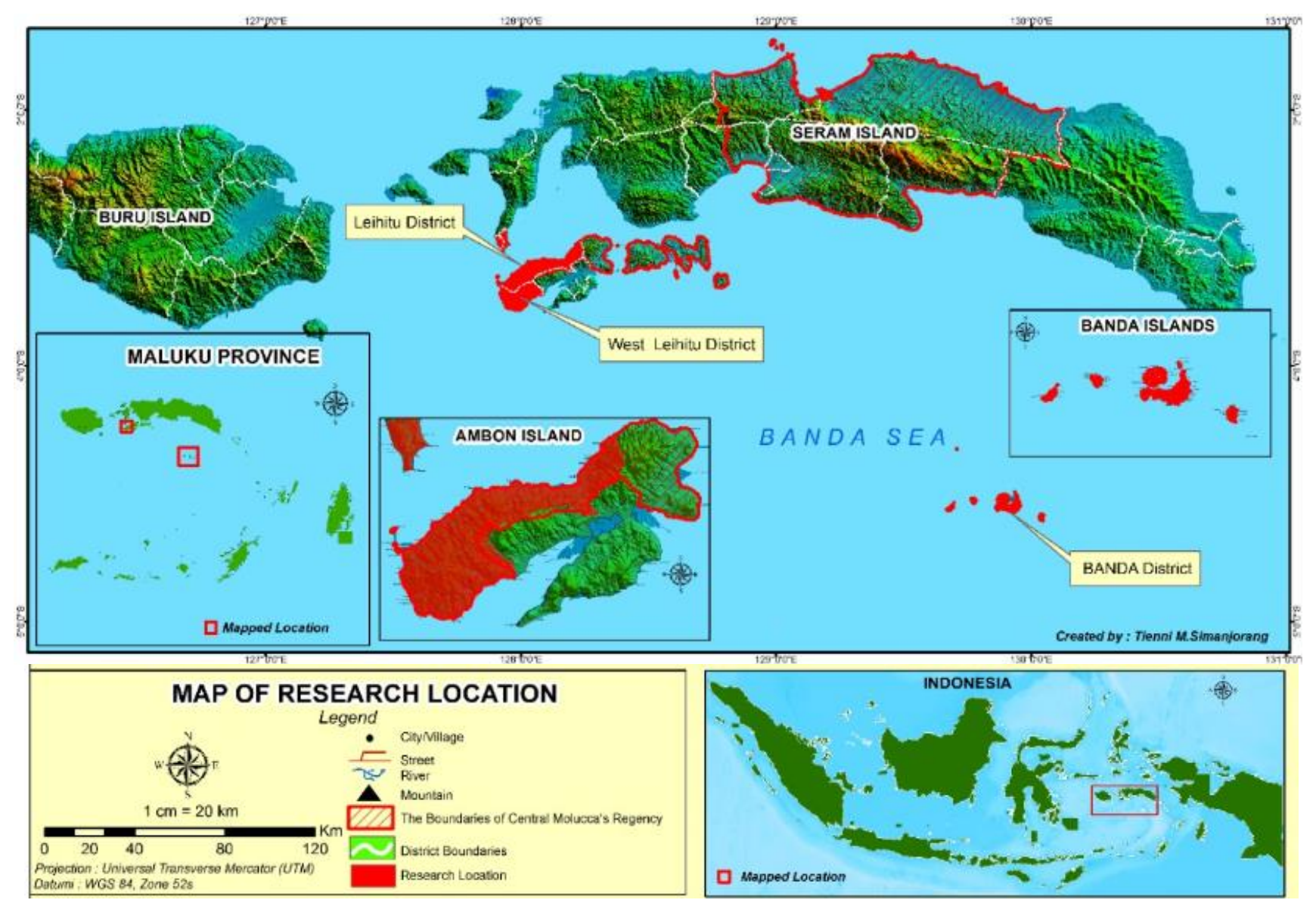

Figure 1. Map of studied areas in the Banda Islands Region and Ambon Island Region. Maluku Province, Indonesia 


\section{Data analysis}

The data was analyzed using the Policy Analysis Matrix (PAM) (Table 1). PAM matrix consists of two identity calculations, namely: profitability identity and identity divergences. In this study, the analysis used was limited to only calculating private benefits, social benefits, competitiveness with competitive and comparative advantage analysis, and different tests on private benefits and social benefits.

Farming competitiveness was measured using a comparative and competitive advantage approach. The comparative advantage of farming was analyzed using the Domestic Resource Cost Ratio (DRCR) approach. The DRCR value is obtained from the Policy Analysis Matrix (PAM) (Monke dan Pearson 1995). Najarzadeh et al. (2011) state that PAM provides a framework that allows calculating the comparative advantage index, competitive advantage, protection coefficient, and competitiveness index simultaneously and can analyze government policies.

The first line in the PAM Matrix in Table 1 is a calculation that uses market prices (private), which is the price paid or received by farmers. The second row in Table 1 is a calculation based on social prices (shadow prices), that is, prices that reflect the actual social value for both the cost and the results. The difference between calculations based on private prices and social prices indicates the impact of policies received by nutmeg farmers. Mobasser et al. (2012) states that the PAM matrix consists of two equations, that is, the matrix of the first row shows income, costs and benefits on the basis of private prices and the matrix of the second row calculates the same amount from the first row on the basis of shadow prices (social prices) (Winarno et al, 2018; Santana et al, 2018).

From the PAM table (Table 1), competitiveness (i.e. comparative advantage and competitive advantage) can be measured nutmeg farming from several indicators (Santana et al, 2018):

Private Benefit (PP) or D = A-B-C. Requirements if the value of $\mathrm{D}>0$, meaning that the commodity system gains above-normal profits, implying that the commodity is capable of expansion. Conversely, if the value of $\mathrm{D} \leq 0$, it means that the commodity system is earning a belownormal profit, implying that the commodity is unable for expansion.

Social Benefit (SP) or H = E-F-G, Requirements if the value of $\mathrm{H}>0$, means that the commodity system is efficient under conditions of no divergence and efficient policy application (Yao, 1999). Conversely, if the value of $\mathrm{H} \leq 0$, means the commodity system cannot compete without government assistance and intervention.

Competitive Excellence $(\mathrm{PCR})=\mathrm{C} /(\mathrm{A}-\mathrm{B})$. When the PCR value $<1$ means the commodity system under study has a competitive advantage. Conversely, if the value of PCR $\geq 1$, the commodity system under study has no competitive advantage. PCR is also called competitiveness ratio (Bernal et al. 2012) and shows the system's ability to pay domestic costs and remain competitive in actual market conditions. The smaller the PCR value means the less domestic costs based on the actual price required to produce output. If the PCR value is less than one, the commodity system is competitive.

Comparative Excellence $($ DRCR $)=\mathrm{G} /(\mathrm{E}-\mathrm{F})$. When the DRCR value $<1$, meaning the commodity system has a comparative advantage. Conversely, if the DRCR value $\geq$ 1 , commodity systems have no comparative advantage. DRCR shows the number of domestic resources that can be saved to produce one foreign-exchange unit. The smaller the value of the DRCR, the higher the comparative advantage.

Determination of the level of competitiveness is based on competitiveness criteria (Table 2), namely from the acquisition of a combined value of private profit, social profit, PCR value, and DRCR value. Determination of the level of competitiveness aims to determine the priority scale of development of products/products for farming or businesses that will be developed.

Table 1. Policy Analysis Matrix (PAM) (Monke and Pearson 1995; Santana et al. 2018)

\begin{tabular}{|c|c|c|c|c|}
\hline \multirow{2}{*}{ Information } & \multirow[b]{2}{*}{ Income } & \multicolumn{2}{|r|}{ Cost } & \multirow{2}{*}{ Profit } \\
\hline & & Input tradable & Input non-tradable & \\
\hline Private Cost & A & $\mathrm{B}$ & 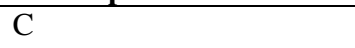 & $\mathrm{D}$ \\
\hline Social Cost & $\mathrm{E}$ & $\mathrm{F}$ & G & $\mathrm{H}$ \\
\hline Policy Impact & $\mathrm{I}=\mathrm{A}-\mathrm{E}$ & $\mathrm{J}=\mathrm{B}-\mathrm{F}$ & $\mathrm{K}=\mathrm{C}-\mathrm{G}$ & $\mathrm{L}$ \\
\hline \multicolumn{4}{|c|}{ Descriptions of Each Indicator } & Formula \\
\hline \multicolumn{4}{|l|}{ Private Profit (PP) } & $A-(B+C)$ or $D$ \\
\hline \multicolumn{4}{|l|}{ Social Profit (SP) } & E- $(F+G)$ or $H$ \\
\hline \multicolumn{4}{|l|}{ Net Transfers (NT) } & $\mathrm{I}-(\mathrm{J}+\mathrm{K})$ or $\mathrm{L}$ \\
\hline \multicolumn{4}{|c|}{ Private Cost Ratio (PCR) } & $\mathrm{C} /(\mathrm{A}-\mathrm{B})$ \\
\hline \multicolumn{4}{|c|}{ Domestic Resource Cost Ratio (DRCR) } & $\mathrm{G} /(\mathrm{E}-\mathrm{F})$ \\
\hline \multicolumn{4}{|c|}{ Nominal Protection Coefficient on Tradable Outputs (NPCO) } & $\mathrm{A} / \mathrm{E}$ \\
\hline \multicolumn{4}{|c|}{ Nominal Protection Coefficient on Tradable Inputs (NPCI) } & $\mathrm{B} / \mathrm{F}$ \\
\hline \multicolumn{4}{|c|}{ Effective Protection Coefficient (EPC) } & $(\mathrm{A}-\mathrm{B}) /(\mathrm{E}-\mathrm{F})$ \\
\hline \multicolumn{4}{|c|}{ Profitability Coefficient (PC) } & $\mathrm{D} / \mathrm{H}$ \\
\hline \multicolumn{4}{|c|}{ Subsidy Ratio to Producers (SRP) } & $(\mathrm{L} / \mathrm{E})$ \\
\hline
\end{tabular}


Table 2. Assessment criteria for competitiveness (Kohari et al. 2005)

\begin{tabular}{llllll}
\hline Indicator & \multicolumn{5}{c}{ Value criteria } \\
\hline PP & + & - & - & - & - \\
SP & + & + & - & - & - \\
PCR & + & + & + & - & - \\
DRCR & + & + & + & + & - \\
Value & $4+$ & $3+, 1-$ & $2+, 2-$ & $1+, 3-$ & $4-$ \\
$\begin{array}{l}\text { Combinations } \\
\text { Competitiveness } \\
\text { level }\end{array}$ & $\begin{array}{l}\text { Very } \\
\text { high }\end{array}$ & High & Medium & Low & Very low \\
\hline
\end{tabular}

The difference in the range of competitiveness of a commodity can be used to determine the priority scale for the development of the commodity concerned (Kohari et al. 2005), namely: (i) commodities that have very high competitiveness means that they can be prioritized to be developed, (ii) commodities that have high competitiveness means that they are still prioritized to be developed, but after the commodities that have very high competitiveness, (iii) commodities that are moderately competitive means that they have two possibilities: it can be developed or cannot be developed, depending on whether it has been in the field and whether there is a policy distortion or because of market failure, and (4) meanwhile, for commodities that have low or very low competitiveness, they do not need to be developed.

\section{RESULTS AND DISCUSSION}

\section{Characteristics of nutmeg farmers in two regions}

Characteristics of the respondents of nutmeg farming in the Banda Islands region and Ambon Island region can generally be classified as middle to lower scale farmers. This is indicated by the area of ownership of land ownership which is still relatively small. The management of nutmeg farming is less intensive, so that the yield produced is still relatively low. Characteristics of respondent farmers in the two studied areas, in terms of age, education, farming experience, number of nutmeg trees owned, the distance of land to the farmer's residence, land area and farm productivity managed by the respondent farmer are presented in Table 3.

Table 3 shows that the average age of farmer respondents in the two regions is still in relatively productive age with 51.82 years in the Banda region and 55.58 years in Ambon Island region. At this productive age, farmers can work optimally to perform maximum work productivity. The average year of education of the farmers in the Ambon Island region is longer than in the Banda Region because the Ambon Island Region is close to the capital of the Maluku Province. Formal education level of the farmers is closely related to the ability of farmers to manage and absorb information related to nutmeg farming. Formal education level of the farmers is still low, so farmers do not have maximum expertise in managing their farming, or in other words, farmers manage nutmeg farming using traditional (less intensive) practice. The experience of farming is closely related to the ability of management in farming. The average length of experience in farming in the Banda Islands region is longer than in Ambon Island region. It shows that farmers in the Banda Islands region are better in the ability to manage their farms so that nutmeg farms in the Banda Islands region have a more significant advantage than those in the Ambon Island region. Farmers in the Banda Islands region are former farmers of the Pala Banda company that has been closed.

Table 3. Characteristics of nutmeg farmers respondents in two regions, Maluku, Indonesia

\begin{tabular}{|c|c|c|c|c|c|c|c|c|}
\hline \multirow{2}{*}{ Variable } & \multicolumn{4}{|c|}{ Banda Islands Region } & \multicolumn{4}{|c|}{ Ambon Island Region } \\
\hline & Min. & Max. & Mean & Std. Dev & Min. & Max. & Mean & Std. Dev \\
\hline Farmer age (year) & 25.00 & 78.00 & 51.82 & 12.98 & 22.00 & 89.00 & 55.58 & 11.85 \\
\hline Formal education level (year) & 6.00 & 17.00 & 8.95 & 2.99 & 4.00 & 17.00 & 9.82 & 3.31 \\
\hline Farming experience (year) & 9.00 & 50.00 & 27.02 & 10.45 & 7.00 & 61.00 & 25.62 & 12.99 \\
\hline $\begin{array}{l}\text { Number of nutmeg trees } \\
\text { owned by farmers (trunks) }\end{array}$ & 139.00 & $3,475.00$ & 488.85 & 459.21 & 106.00 & $1,112.00$ & 382.95 & 236.19 \\
\hline $\begin{array}{l}\text { Land distance to farmer's } \\
\text { residence (meter) }\end{array}$ & 200.00 & $10,000.00$ & $1,989.17$ & $1,712.19$ & 100.00 & $7,000.00$ & $2,010.00$ & 1402.14 \\
\hline $\begin{array}{l}\text { Land area }\left(\mathrm{m}^{2} / \text { farmer }\right) \\
\text { Productivity of nutmeg } \\
\text { farming }\end{array}$ & $5,000.00$ & $75,000.00$ & $16,750.00$ & $11,509.94$ & $3,800.00$ & $60,000.00$ & $14,532.79$ & $10,296.31$ \\
\hline Seeds of nutmeg $(\mathrm{kg} /$ tree $)$ & 0.008 & 1.28 & 0.23 & 0.23 & 0.008 & 1.15 & 0.24 & 0.25 \\
\hline Mace (kg/tree) & 0.002 & 0.15 & 0.04 & 0.04 & 0.001 & 0.16 & 0.04 & 0.03 \\
\hline
\end{tabular}


The area of land and the number of nutmeg trees owned by farmers in the Banda Islands region are larger than in the Ambon Island region because farmers in the Banda Islands region have managed their businesses more intensively, and farming has become the main livelihood for the farmers. Farm productivity in the two regions studied is not much different, meaning that the average productivity of nutmeg seeds is $0.23 \mathrm{~kg} /$ tree in the Banda Islands region and $0.24 \mathrm{~kg} /$ tree in Ambon Island region. The average mace yield productivity in the two regions is $0.04 \mathrm{~kg} / \mathrm{tree}$. The average distance of land to farmers' homes is farther in the Ambon Island region than in the Banda Islands region. This distance affects the costs incurred by farmers in farming. The average distance of land to the residence of farmers in the Ambon Island region is farther due to the location of farming land in community forests, so that management is not optimal, and the costs incurred mainly the family labor costs are higher than in the Banda Islands region.

\section{Private costs and social costs of nutmeg farming in two regions}

Nutmeg plantations in two regions (i.e. Ambon Island region and Banda Islands region) use simple/traditional technology with the use of straight forward inputs. Even though it uses simple technology, the products of nutmeg farming become a profitable export commodity. The nutmeg plantations is managed by a polyculture system and is planted irregularly, so the costs of inputs, revenues, and profits are calculated per nutmeg tree. Analysis of the competitiveness and efficiency of the annual crop system requires a discount process to get the present value (Basavaraj et al, 2013; Rashid and Matin, 2018) because nutmeg has a production period of up to 100 years (Ruhnayat dan Martini, 2015). Before obtaining the results of the PAM matrix, it is necessary to group the input costs incurred on the farm (Table 4).

The seeds used in nutmeg farming are originated from local seedlings in the study area. The procurement of seeds is not subject to tax or government subsidies because the seedlings planted are taken from local sources. The labor used in nutmeg farming is family labor and it does activities of planting, maintaining until harvest, and postharvest. The private costs of family labor are obtained from the actual value of wage labor in the study area. The social price of wage labor is calculated based on its private price and multiplied by the number of the working population, which is $94.87 \%$ for Maluku Province. That is because of the implementation of government policies in the form of regional minimum wages so that when the private price of the policy is eliminated, and social labor costs are cheaper. The social price of labor wages in nutmeg farming is IDR70,274/person/day (BPS of Maluku Province, 2018).

The equipment used is equipment that is traded and non-traded, resulting in differences in private costs and social costs. Equipment used in this nutmeg farming such as hoes, machetes, sickles, baskets, and others. Depreciation of plants is obtained from the total costs incurred when the plant is 0 years old until the first production (6 years) divided by the productive age of nutmeg plants that is 100 years. Farmers rely more on the use of non-tradable inputs in nutmeg farming in the two areas studied so that the input costs both privately and socially, are relatively small.

\section{Private benefits and social benefits of nutmeg farming in two regions}

Farmers who are interested in the benefits of farming and the costs incurred by new technology and like to know the risks arising from farming practices are very important for conducting economic analysis (Jabbar et al. 2009). The difference between private benefits and social benefits occurs because of the evaluation of the elements of revenue and costs. Private profit is calculated based on the actual price received by farmers, while social benefits are obtained in the event of a perfectly competitive market, where there is no market failure and government intervention (policy). The success of a business/farm can be seen from the benefits obtained or often also referred to as the economic performance of a business (Farah and Ramos, 2014; Ouakli et al. 2018). Empirical construction of PAM consists of the private and social value of income (price multiplied by the amount produced), production costs/inputs (the number of domestic/non-tradable inputs and tradable inputs) and profits (the difference between income and costs) (Santana et al, 2018).

The competitiveness of nutmeg farming is aimed to assess the competitiveness of nutmeg farming in different areas in Maluku Province. Nutmeg farming carried out in the areas of the Banda Islands region and Ambon Island region is done traditionally. Although classified as traditional farming, the products produced by nutmeg farming in the form of seeds and mace are exported and very popular in the international market. To determine the market viability of these products, the competitiveness needs to be analyzed. Table 5 presents a matrix assessment of private benefits and social benefits of smallholder farming based on the Policy Analysis Matrix (PAM).

Table 4. Average private costs and social costs of nutmeg farming in two regions, Maluku, Indonesia

\begin{tabular}{|c|c|c|c|c|}
\hline \multirow{2}{*}{ Kind of cost } & \multicolumn{2}{|c|}{ Private cost (IDR/tree/year) } & \multicolumn{2}{|c|}{ Social cost (IDR/tree/year) } \\
\hline & Banda Islands & Ambon Island & Banda Islands & Ambon Island \\
\hline Seeds & 44 & 42 & 44 & 42 \\
\hline Family labor & 9,128 & 9,336 & 6,412 & 6,560 \\
\hline Shrinkage of equipment & 404 & 416 & 400 & 412 \\
\hline Shrinkage of plants & 44 & 44 & 44 & 44 \\
\hline Land lease & 2,506 & 2,190 & 2,482 & 2,168 \\
\hline Total input costs & 12,126 & 12,028 & 9,382 & 9,226 \\
\hline
\end{tabular}


Table 5. Results of analysis of nutmeg farming policy matrix in two regions, Maluku, Indonesia

\begin{tabular}{lcccccc}
\hline \multirow{2}{*}{ Item } & \multicolumn{2}{c}{ Banda Islands Region (IDR/tree/year) } & \multicolumn{2}{c}{ Ambon Island Region (IDR/tree/year) } \\
\cline { 2 - 7 } & Privat Price & Sosial Price & Divergence & Privat Price & Sosial Price & Divergence \\
\hline Income & 31,831 & 63,394 & $-31,562$ & 18,645 & 45,163 & $-26,518$ \\
Tradable Input & 0.7654 & 0.7578 & 0.0076 & 0.3626 & 0.359 & 0.0036 \\
Non Tradable Input & 12,124 & 9,380 & 2,744 & 12,028 & 9,226 & 2,802 \\
Profit & 19,706 & 54,012 & $-34,306$ & 6,617 & 35,937 & $-29,320$ \\
\hline
\end{tabular}

Farm receipts are obtained by multiplying the amount of output produced at the selling price. The private price on private revenue is based on the selling price received by farmers in the Banda Islands region; the price of nutmeg seeds is IDR75,000/kg, and the nutmeg flower is IDR165,000/kg, whereas, in Ambon Island region, the price of nutmeg seeds is in the range of IDR40,000/kgIDR $70,000 / \mathrm{kg}$ and the price of nutmeg/mace are in the range of IDR $80,000 / \mathrm{kg}$-IDR $145,000 / \mathrm{kg}$. Private prices in the two regions studied are different. The private prices of nutmeg and nutmeg at the farmer level in the Banda Islands region are higher than those in the Ambon Island region. This price difference occurs because the marketing system of nutmeg farms in the Banda Islands region is directly sold to exporters so that the quality of the products is guaranteed. This quality is one of the determinants of prices obtained by farmers. According to large traders/exporters, the quality of nutmeg and nutmeg seeds from the Banda Islands region is better or has higher quality. The farmers have sorted the quality of the products when they are sold to exporters. In the Ambon Island region, farmers sell their farming products to small traders, intermediaries, and collectors. Most farmers in the Ambon Island region do not sort the quality of the nutmeg farms sold, so the prices received are different from that in the Banda Islands region. This means that the high quality of a nutmeg product is in line with the high price set on a product.

Social prices are used to determine the social benefits of nutmeg farming based free on board price of IDR147,083/kg of nutmeg and IDR340,894/kg of mace. Table 5 also shows that the social price of nutmeg farming is higher than the private price, suggesting that the prices applied in both the Banda Islands region and Ambon Island region are below international prices. There are policy distortions that do not protect producers, thus directly affecting farm profits (Santana et al. 2018). Based on differences in private prices and social prices obtained indicate a policy distortion that does not protect producers. Private profit is derived from the reduction in private income less the cost of tradable and non-tradable inputs in private prices. Social benefits are derived from the reduction in social income, lowering the costs of tradable and non-tradable inputs in social prices. Nutmeg farming in the two regions studied has private benefits and positive social benefits, which means that they are profitable and able to expand.

The private profit of nutmeg farming in the Banda Islands region is higher (IDR19,706/tree/year) compared to the private profit of nutmeg farming in the Ambon Island region (IDR6,617/tree/year) because the price of farms obtained is higher in the Banda Islands region. The high price obtained is due to the trading system which is carried out by direct farmers to big traders or exporter. Besides, the quality of nutmeg products in the Banda Islands region is more qualified and guaranteed. This high private price gives a higher private profit in the Banda Islands region compared to the Ambon Island region, considering the input costs incurred in the two regions are not much different. The yield of nutmeg products produced in the Banda Islands region is higher than in the Ambon region because the farming/management system in the Banda Islands region is carried out intensively starting from planting, maintenance, harvesting, and postharvest. Farmers manage their farming intensively because this nutmeg farming is the primary source of livelihood in the Banda Islands region. Due to the intensive management and becoming the primary source of livelihood, the farmers in the Banda Islands region tend to be profit-oriented. Intensive farming management will increase farmers' income/profits in farming (Ugochukuwu and Ezedinma, 2011). Farmers in the Banda Islands region can manage nutmeg farming intensively from the process of planting to harvest and post-harvest and marketing because the nutmeg farmers are former farmers employed by the private company Pala Banda that has been closed. In the Ambon Island region, nutmeg farmers have not yet managed intensively nutmeg farming but tend to leave nutmeg plants without care because these farmers are Ambon farmers who are ordinary farmers (not partners of nutmeg companies), besides nutmeg farming is not the primary source of livelihood for some a large nutmeg farmer on Ambon Island region.

Private and social benefits obtained show that farm performance provides benefits so that nutmeg farming can be sustained (Ouakli et al. 2018). The private and social benefits of nutmeg business in both regions (Banda Islands region and Ambon Island region) are positive (beneficial). This result is in accordance with previous research on competitive and comparative advantages of nutmeg and nutmeg farming in the North Minahasa region (Gerungan et al. 2010) and in the districts of Bogor and Sukabumi (Hasibuan et al. 2012). The social benefits of nutmeg farming in the two regions studied are positive (socially/economically beneficial). Social benefits show that nutmeg farming is economically efficient. The highest social benefit of nutmeg farming is in the Banda Islands region. 
The value of profit divergence in the Banda Islands region worth IDR-34,306, and the value of profit divergence in the Ambon Islands worth IDR-29,320. The value of the profit divergence obtained in both regions is negative, meaning that existing government policies do not favor farmers because the determination of the actual price/output price received by farmers happens without government intervention. The price received by farmers is in a free market position without government protection and without government control resulting in the price of social output being higher than the actual price received by farmers (Najarzadeh et al. 2011).

Different tests were carried out to find out whether there were differences in the benefits of nutmeg farmers in two different regions in Maluku Province. This different test was carried out to clarify that there were differences in private benefits and social benefits of smallholder farming (Table 6).

The independent t-test shows that the private advantages and social benefits of nutmeg farming in the two regions were significant differences (Table 6). The reason for the differences in private prices of the nutmeg farming is because the private prices of the commodities produced from the nutmeg farming at the farm level are higher in the Banda Islands Region than in the Ambon Island region. The difference in price and the amount of product obtained is the main factor that makes private income different. The determination of private prices is due to the different marketing chain systems in the two regions. In the Banda Islands region, the marketing chain of farm products is carried out directly to significant traders/exporter. Whereas in the Ambon Island region, the marketing system of nutmeg farms is sold through small traders, then small traders sell to big traders who export nutmeg farms out of Maluku province while the main factor in the occurrence of differences in social benefits in this study is the amount of production obtained by farmers from nutmeg farming.

\section{Competitive advantage, comparative advantage, and competitiveness of nutmeg farming}

Analysis of competitive advantage and comparative advantage comes from the measurement of indicators obtained in the empirical construction of the PAM matrix (Adesina and Coulibaly, 1998; Arsanti and Böhme, 2008; Antriyandarti, 2015). The competitiveness of the commodity can show the superiority of a commodity. Such competitiveness can be seen from competitive and comparative advantages. Competitive advantage shows the efficient use of domestic production factors in providing value-added products in the domestic market as measured by the value of the Private Cost Ratio (PCR) (Santana et al. 2018). Comparative advantage is used to measure the efficiency of using domestic production factors in generating additional foreign exchange (if including export products) or saving foreign exchange (if including imported products) measured by the value of the Domestic Resources Cost Ratio (DRCR) (Winarno et al. 2018; Santana et al. 2018).

The difference between the PRC and DRCR assessments lies in the cost of private and social domestic (non-tradable) factor costs. PCR analysis is usually also referred to as financial efficiency analysis, which is calculated by the price received or issued by farmers (private prices). The private price has been influenced by government policies such as subsidies, protection, import duty/exemption, taxes, and other policies. DRCR analysis is usually called economic efficiency analysis, which takes into account the economy as a whole without taking into account government policies (Zheng et al. 2013; Alves et al. 2017). The value of PCR and DRCR from nutmeg farming can be seen in Table 7 .

Private and social benefits will have an impact on the competitive advantage and comparative advantage of a farm. It is proven by the large private profit or a positive value indicating that nutmeg farming has a competitive advantage. The social benefits obtained are positive, indicating that nutmeg farming has a comparative advantage. From the indicators of competitiveness obtained, the competitiveness level of the commodity can be measured by referring to four elements of valuation, namely private profit, social profit, PCR, and DRCR.

Based on assessment criteria for competitiveness (Table 2 ), the results of the analysis (Table 7) show that nutmeg farming in both regions has a competitive advantage or is financially said to be efficient because of the value of the private cost ratio (PCR) is smaller than one. The value of PCR nutmeg farming in the Banda Islands region is 0.38 , which means it has a competitive advantage. The competitive advantage of nutmeg farming is higher in the Banda Islands region than in the Ambon Island region. The value of PCR nutmeg farming on Ambon Island region is 0.65 , which means it has a competitive advantage or financially efficient. This study is in line with previous studies conducted in North Minahasa (Gerungan et al, 2010), in Bogor and Sukabumi Districts (Hasibuan et al, 2012) which found that nutmeg farming has comparative and competitive advantages.

Table 6. Results of different tests of private benefits of nutmeg farming in two regions in Maluku, Indonesian

\begin{tabular}{|c|c|c|c|c|c|}
\hline \multirow{2}{*}{ Difference test } & & \multicolumn{2}{|c|}{$\begin{array}{c}\text { Private benefit } \\
\text { Banda Islands - Ambon Island }\end{array}$} & \multicolumn{2}{|c|}{$\begin{array}{c}\text { Social benefit } \\
\text { Banda Islands - Ambon Island }\end{array}$} \\
\hline & & $\begin{array}{c}\text { Equal variances } \\
\text { assumed }\end{array}$ & $\begin{array}{c}\text { Equal variances } \\
\text { not assumed }\end{array}$ & $\begin{array}{c}\text { Equal variances } \\
\text { assumed }\end{array}$ & $\begin{array}{c}\text { Equal variances } \\
\text { not assumed }\end{array}$ \\
\hline Levene's test for equality & $\mathrm{F}$ & 36.814 & & 29.293 & \\
\hline of variances & Sig & 0 & & 0 & \\
\hline t-test for equality & $\mathrm{t}$ & 3.241 & 3.241 & 2.145 & 2.145 \\
\hline of means & Sig. (2-tailed) & 0.002 & 0.002 & 0.034 & 0.034 \\
\hline
\end{tabular}


Table 7. Coefficient indicators of competitive advantage, comparative advantage and competitiveness level of nutmeg farming in two region, Maluku Province, Indonesia

\begin{tabular}{lll}
\hline Description & Banda & Ambon \\
\hline Private Profit (PP) & 19,706 & 6,617 \\
Social Profit (SP) & 54,012 & 35,937 \\
Private Cost Ratio (PCR) & 0.38 & 0.65 \\
Domestic Resources Cost Ratio (DRCR) & 0.15 & 0.20 \\
\hline
\end{tabular}

The coefficient value of the ratio of domestic resource costs (DRCR) from smallholder farming in the Banda Islands region and Ambon Island region is smaller than one, which shows that nutmeg farming has a comparative advantage or is said to be economically efficient. The comparative advantage of nutmeg farming in the Banda Islands region is higher than in the Ambon Island region because, with the resources owned/issued, nutmeg farming in the Banda Islands region has a comparative advantage higher than in the Ambon Island region. The nutmeg farm DRCR value is lower than the PCR value (DRCR $<\mathrm{PCR}$ ), meaning that the existence of government policy in producing a unit of added value requires a unit factor that is greater than in the absence of government policy. Thus the government must consider existing policies or make other policies that can protect farmers (Gerungan et al. 2010).

An assessment of the level of competitiveness is needed to determine the priority of developing agricultural products. The determination of these priorities is based on evaluating the level of competitiveness of a product/business being carried out. Assessments on the level of competitiveness are based on the value of private profit, social profit, a ratio of private costs, and the ratio of domestic resource costs (Kohari et al. (2005).

The level of competitiveness of the nutmeg in the two research areas is in a very high competitiveness position (Table 7). The level of competitiveness of nutmeg farming in the Banda Islands region is better in terms of higher private and social benefits than in the Ambon Island region. The value of PCR and DRCR of nutmeg farming in the Banda region is smaller than that of the Ambon Island region, meaning that the nutmeg farming in the Banda Islands region has a better competitive and comparative advantage compared to the Ambon Island region.

It can be concluded that nutmeg farming in the two studied regions has private benefits and positive social benefits (beneficial). The highest private and social benefits of nutmeg farming have resulted from the Banda Islands region. Nutmeg farming has competitive and comparative advantages in the two regions studied which can be seen from the value of PCR and DRCR smaller than one. The Banda Islands region has a competitive advantage and is comparatively better than the Ambon Island region because the value of the PCR and DRCR obtained is smaller than the value of the PCR and DRCR in Ambon Island region. The competitiveness of nutmeg farming in the Banda Islands region is more competitive because private and social benefits are higher, and PCR and DRCR values are lower than in the Ambon Island region. There is a significant difference in the private and social benefits gained in the two regions studied. Nutmeg farming remains a priority sector for business development in the two regions studied in Maluku Province. Intensive farming management will provide benefits, competitive advantage, comparative advantage, high competitiveness for a farm. The policy implications in nutmeg farming are input subsidy policies as outlined in Presidential Regulation Number 15 of 2011, and harvest, postharvest management policies and product quality standards as outlined in Regulation of the Minister of Agriculture of the Republic of Indonesia Number 53/ Permentan/Ot.140 / 9/2012 "Regarding Guidelines for Handling Nutmeg Postharvest".

\section{ACKNOWLEDGEMENTS}

The author would like to thank Indonesia Endowment Fund for Education (LPDP), the Indonesian Ministry of Finance, who funded this research.

\section{REFERENCES}

Adesina AA, Coulibaly ON. 1998. Policy and competitiveness of agroforestry-based technologies for maize production in cameroon: an application of policy analysis matrix. Agric Econ 19: 1-13

Alves CES, Belarmino LC, Padula AD. 2017. Feedstock diversification for biodiesel production in Brazil: Using The Policy Analysis Matrix (PAM) to evaluate the impact of the PNPB and the economic competitiveness of alternative oilseeds. Energ Pol 109: 297-309.

Antriyandarti E. 2015. Competitiveness and cost efficiency of rice farming in Indonesia. J Rural Probl 51 (2), 74-85

Arsanti IW, Böhme MH. 2008. Evaluation of profitability and competitiveness of vegetable farming systems in upland areas of Indonesia. Acta Hortic 794: 49-54.

Basavaraj G, Rao PP, Achoth L, Reddy ChR. 2013. Assessing competitiveness of sweet sorghum for ethanol production: a policy analysis matrix approach. Agric Econ Res Rev 26 (1): 31-40.

Bernal LEP, Herrera AL, Rivas ER, Veyna OP. 2012. Competitiveness, efficiency, and environmental impact of protected agriculture in Zacatecas, Mexico. Intl Food Agribus Manag Rev 15 (4): 49-64.

BPS of Maluku Province. 2018. Maluku in Figures 2018. Badan Pusat Statistik Provinsi Maluku, Ambon.

Dattalo P. 2008. Determining Sample Size: Balancing Power, Precision, and Practicality. Pocket guides to Social Work Research Methods. Oxford University Press, Oxford.

Farah AB, Ramos AG. 2014. Competitiveness vs. sustainability: an assessment of profitability as a component of an approach on "sustainable competitiveness" in extensive farming systems of Central Spain. J Sustainability 6: 8029-8055. DOI: 10.3390/su6118029

Gerungan LM, Pakasi CBD, Dumais JNK, Sondak LWTh. 2010. Analysis of comparative and competitive advantages of nutmeg commodities in North Minahasa. Jurusan Sosial Ekonomi, Fakultas Pertanian. Universitas Samratulangi, Manado. [Indonesian]

Hasibuan AM, Sudjarmoko B, Listyati D. 2012. Analisis keunggulan komparatif dan kompetitif usahatani pala (Studi Kasus: Kabupaten Bogor dan Sukabumi). Buletin RISTRI 3 (3): 223-230. [Indonesian]

Jabbar A, Ahmad R, Bhatti IH, Virk ZA, Wasi-U-Din, Khan MM. 2009. Assessment of yield advantages, competitiveness and economic benefits of diversified direct-seeded upland rice-based intercropping systems under strip geometry of planting. Pak J Agri Sci 46 (2): 96101.

Jambor A, Toth AT, Koroshegyi D. 2018. Competitiveness in the trade of spices: a global evidence. Bulgarian J Agric Sci 24 (5): $729-736$ 
Kohari K, Ma'sum M, Windiastuti D. 2005. Dampak Kebijakan dan Pemasaran Terhadap Daya Saing Usahatani Kentang di Kecamatan Kejajar Kabupaten Wonosobo. Laporan Penelitian. Fakultas Pertanian UNSOED, Purwokerto. [Indonesian]

Mobasser HR, Rastegaripour F, Tavassoli A. 2012. Study of effects of policy analysis matrix and relative advantage of rapeseed production (case study: sistan region). Intl J Agric Crop Sci 4 (19): 1421 -1425.

Mohammadi D. 2004. Determine the comparative advantage and oilseeds review manufacturing problems in Fars Province. J Agric Econ Develop 47: 125-170.

Monke EA, Pearson SR. 1995. Policy Analysis Matrix for Agricultural Development. Cornell University Press, Ithaca, New York.

Najarzadeh R, Rezagholizadeh M, Saghaian S, Reed M, Aghaie M. 2011. The impact of trade liberalization on Persian rugs: a policy analysis matrix approach. J Food Distrib Res 42 (1): 91 -95.

Nayantakaningtyas JS, Daryanto HK. 2012. Competitiveness and strategy of palm oil development in Indonesia. J Manag Agribus 9: 194-201

Ouakli K, Benidir M, Ikhlef S, Ikhlef H. 2018. Typological analysis of the sustainability of dairy cattle farming in the Chelif valley (Algeria). Agron Res 16 (1): 198-211.

Rahman S, Kazal MMH, Begum IA, Alam MJ. 2016. Competitiveness, profitability, input demand and output supply of maize production in Bangladesh. Agriculture 6: 21. DOI: 10.3390/agriculture6020021

Rashid MA, Matin MA. 2018. The policy analysis matrix of pulse crop production in Bangladesh. Bangladesh J Agril Res 43 (1): 109-123.

Ruhnayat A, Martini E. 2015. Guidelines for Nutmeg Cultivation in Mixed Gardens. World Agroforestry Centre (ICRAF) Southeast Asia Regional Program, Bogor, Indonesia.

Salam A, Tufail S. 2014. Competitiveness and comparativeness advantage of important food and industrial crops in Punjab: application of policy analysis matrix. J Intl Agric Trade Dev 10 (1): 81-94.
Santana AS, Soares NS, Schröder CA. 2018. Competitiveness and efficient for the rubber tree production system in Southern Bahia (Brazil) through by the policy analysis matrix (PAM). Revista Árvore 42 (6): e420606. DOI: 10.1590/1806-90882018000600006

Shahnvshy N, Dehghanian S, Mohammad G, Azarinfar YA. 2007. Comparative advantage analysis of cereals in Khorasan province. J Agric Sci Nat Resour 14: 1-19.

Sousa GS, Saucer MM, Rosy PL. 2011. Effects of competitiveness and efficiency policies of the palm oil biodiesel production chain in the region from the lower south of Bahia. J Rev Árvore Econ Northeast 42 (4): 827-42.

Stephenson S, Erwidodo. 1995. The Impact Uruguay Round in Indonesia Agricultural Sector. The Minister of Agriculture, Jakarta

Ugochukuwu AI, Ezedinma CI. 2011. Intensification of rice production system in southeastern Nigeria: A policy analysis matrix approach. Intl J Agric Manag Dev 1 (2): 89-100.

Winarno ST, Darsono, Harisudin M, Sudiyarto. 2018. Competitiveness analysis of robusta coffee in East Java, Indonesia. Acad Strat Manag J $17(6)$ :.

Yao S. 1999. Efficiency impacts of government policy on agricultural production in presence of externalities. J Environ Manag 55 (1): 57 67.

Zare A. 2008. Comparative advantage in the production of peanuts. J Agric Sci 18 (2): 36-27.

Zheng S, Lambert D, Wang S, Wang Z. 2013. Effects of agricultural subsidy policies on comparative advantage and production protection in china an application with a policy analysis matrix model. Chinese Econ 46 (1): 20-37.

Zhong F, Xu ZG, Fu LB. 2001. Regional Comparative Advantage in China's Main Grain Crops, Australian Centre for International Agricultural Research (ACIAR), Canberra. 